\title{
Ayak bileği ve distal tibia anatomisi
}

\author{
Anatomy of ankle and distal tibia
}

\author{
Mutlu Akdoğan, Yalım Ateş
}

Dışkapı Yıldırım Beyazıt Eğitim ve Araştırma Hastanesi, Ortopedi ve Travmatoloji Kliniği, Ankara

\begin{abstract}
Ayak bileği eklemi, ayakta sabit durmak, yürümek ve koşmak gibi aktivitelerde oldukça ciddi görevleri olan sağlam bir eklemdir. Spor yaralanmaları başta olmak üzere sıklıkla travmaya maruz kalmaktadır. Ayak bileğinde, travma hasarını iyi anlamak, cerrahi veya cerrahi dışı tedaviyi iyi planlamak için en önemli kavramlar: fonksiyonel anatomi ve ayak bileği stabilitesidir. Ayak bileği anatomisi konusu altında, ayak bileğinin kemik, bağ yapılarından; komşu yumuşak dokulardan ve eklemin biyomekaniğinden bahsedilecektir.
\end{abstract}

Anahtar sözcülkler: ayak bileği anatomisi; ayak bilek biyomekaniği
Ankle is a vigorous articulation to perform standing still, walking and running tasks. It usually suffers damage, especially in sports injuries. Functional anatomy and ankle mortis stability are the concepts to be known in deciding surgical or nonsurgical treatment of these injuries. Under the subject of ankle mortis anatomy, bony structures, ligamentous structures, accompanying soft tissue structures and ankle mortis biomechanics will be discussed.

Key words: ankle mortis anatomy; ankle mortis biomechanics

alt uç ön-dış kısmında anterior tibiofibular bağın yapıştığı bir tüberkül vardır (tuberkulum anterior tibia). Chaput tüberkülü olarak da adlandırılır. Tibianın arka dış kısmında posterior tibiofibular bağın yapıştığı, tuberkulum posterior tibia veya Wolkman tüberkülü bulunur. Mediyal malleolün tibia plafondunun bittiği yerden başlayarak talusla olan eklem yüzeyini arttıran konveks kısmı anterior ve posterior kollikulus olarak adlandırılır. Deltoid bağın yüzeyel lifleri ön kollikulusa yapışır. Her iki kollikulus arasında derin bir oluk oluşur. İnterkolliküler oluğa ve arka kollikulusa deltoid bağın derin lifleri yapışır.

Fibula distalde lateral malleol adını alır. Lateral malleol sindezmotik bir eklemle tibiayla, daha distalde ise talusla eklemleşir. Lateral malleolun eklem yüzeyi konveks bir şekildedir. Ön ve arkada tibiofibular bağların fibuladaki yapışma yerleri olan fibular tüberküller, tibia plafondunun hemen distalinde bulunur. Lateral malleolün distalinde posteriorda peroneus longus ve brevis kas tendonlarının geçtiği oluk bulunur.

Eklem kapsülü gevşek ve ince bir yapıdır. Sinovya, eklem kapsülünün iç yüzeyini tamamen örter. Önde tibia ve fibula distalinden talus boynuna kadar uzanır. ile eklemleşen "incisura fibularis tibia" bulunur. Tibia

- İletişim adresi: Op. Dr. Mutlu Akdoğan, Dışkapı Yıldırım Beyazıt Eğitim ve Araştırma Hastanesi, Ortopedi ve Travmatoloji Kliniği, İrfan Baştuğ Cad. Altındağ, Ankara Tel: 0532 - 2040142 e-posta: mutluakdogan@yahoo.com

- Geliş tarihi: 3 Mayıs $2016 \quad$ Kabul tarihi: 3 Mayıs 2016 


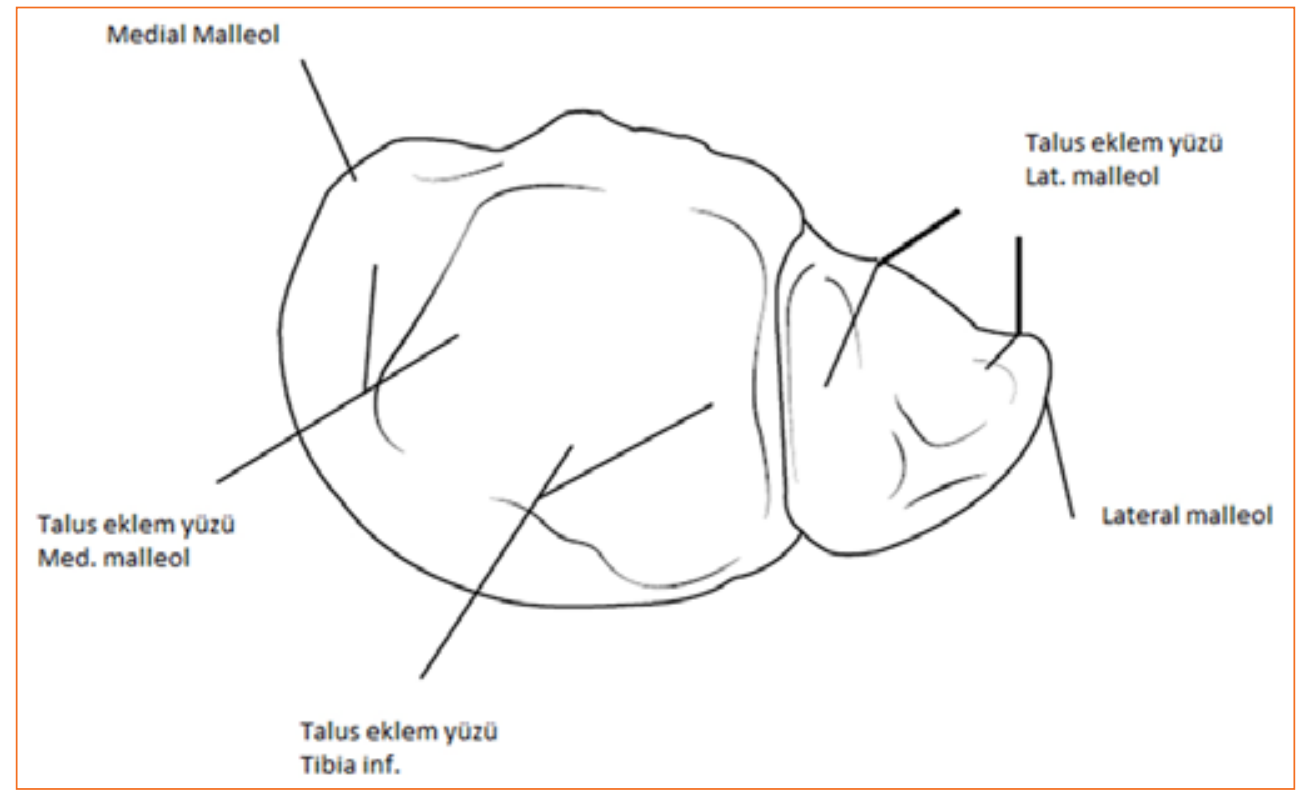

Şekil 1. Ayak bileği eklem yüzü (alttan görünüm).

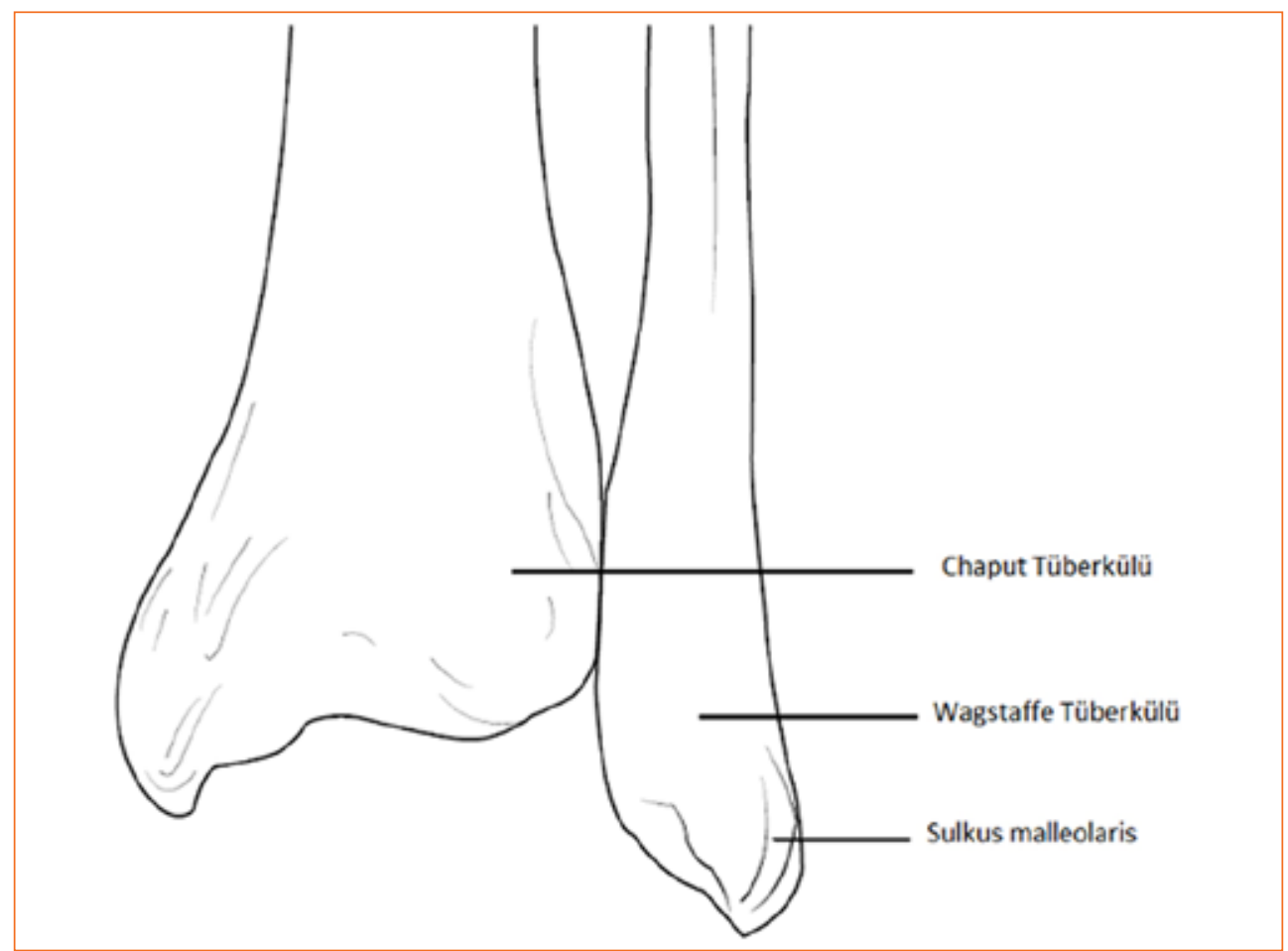

Şekil 2. Ayak bileği kemik yapılar (önden görünüm).

Arkada transvers olarak iki kemik arasında uzanır. Yanlarda malleoller üzerine çıkmaz. ${ }^{[5]}$

Ayak bileğini oluşturan üç kemik yapı, arasında üç eklem bulunmakta olup; bunlar birbirlerine sıkı bağlarla bağlıdır. Bu bağlar, üç gruptan oluşur (Şekil 3 ve 4). ${ }^{[1,5]}$
1- Lateral kollateral bağ kompleksi: Ayak bileğinde talusun lateral ve ön-arka planda stabilitesini sağlar. Anterior talofibular, posterior talofibular ve kalkaneofibular bağ olmak üzere üç gruptan oluşur. (Şekil 3). 


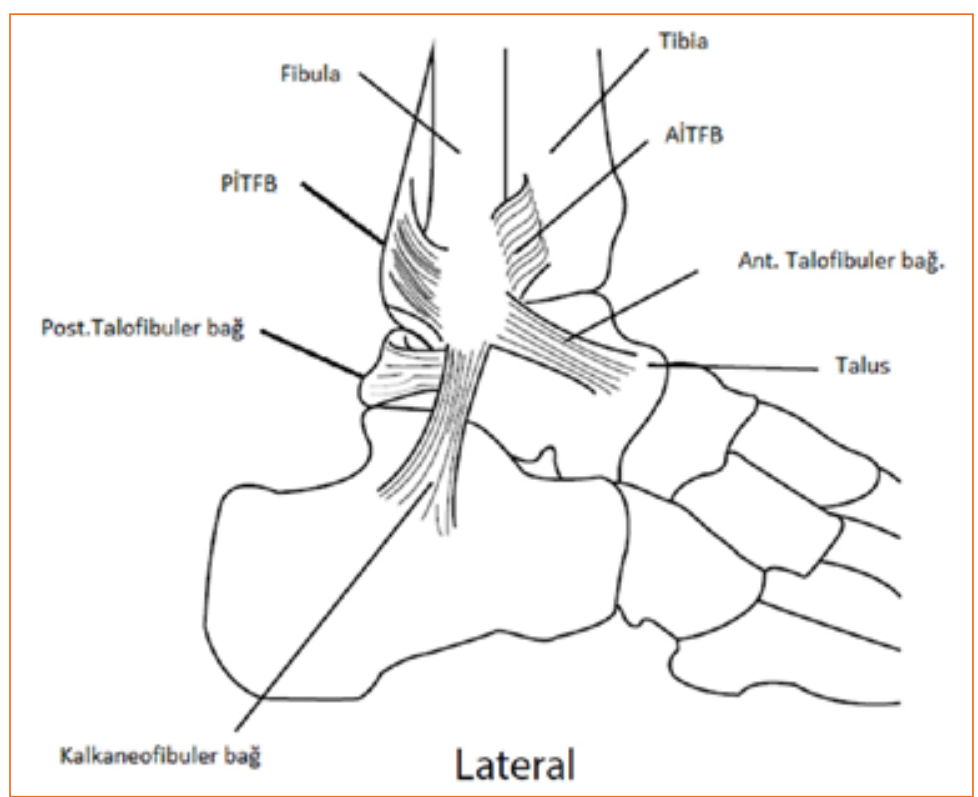

Şekil 3. Ayak bileği bağları (lateral görünüm).

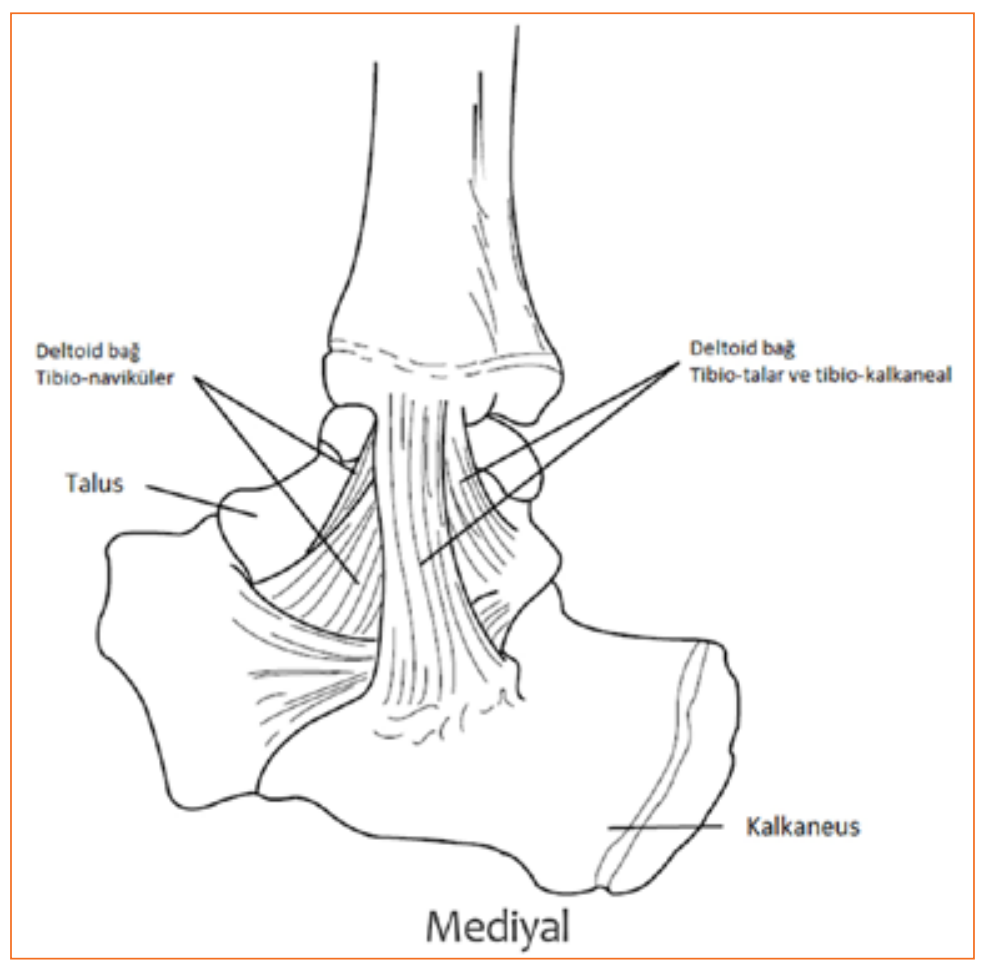

Şekil 4. Ayak bileği bağları (mediyal görünüm).

a- Anterior talofibular bağ: Fibula distaliyle talusun boynu arasındadır. Ayak bileğinin en zayıf bağıdır.

b- Posterior talofibular bağ: Fibula distalinde, posteromediyaldeki eklem dışı bölümden başlar, talus lateral tüberkülüne yapışır. En güçlü lateral bağdır.

c- Kalkaneofibular bağ: Fibula distal posteriorundan kalkaneus lateralinde arka faset eklemin distaline uzanır. Ayağın inversiyonunu 


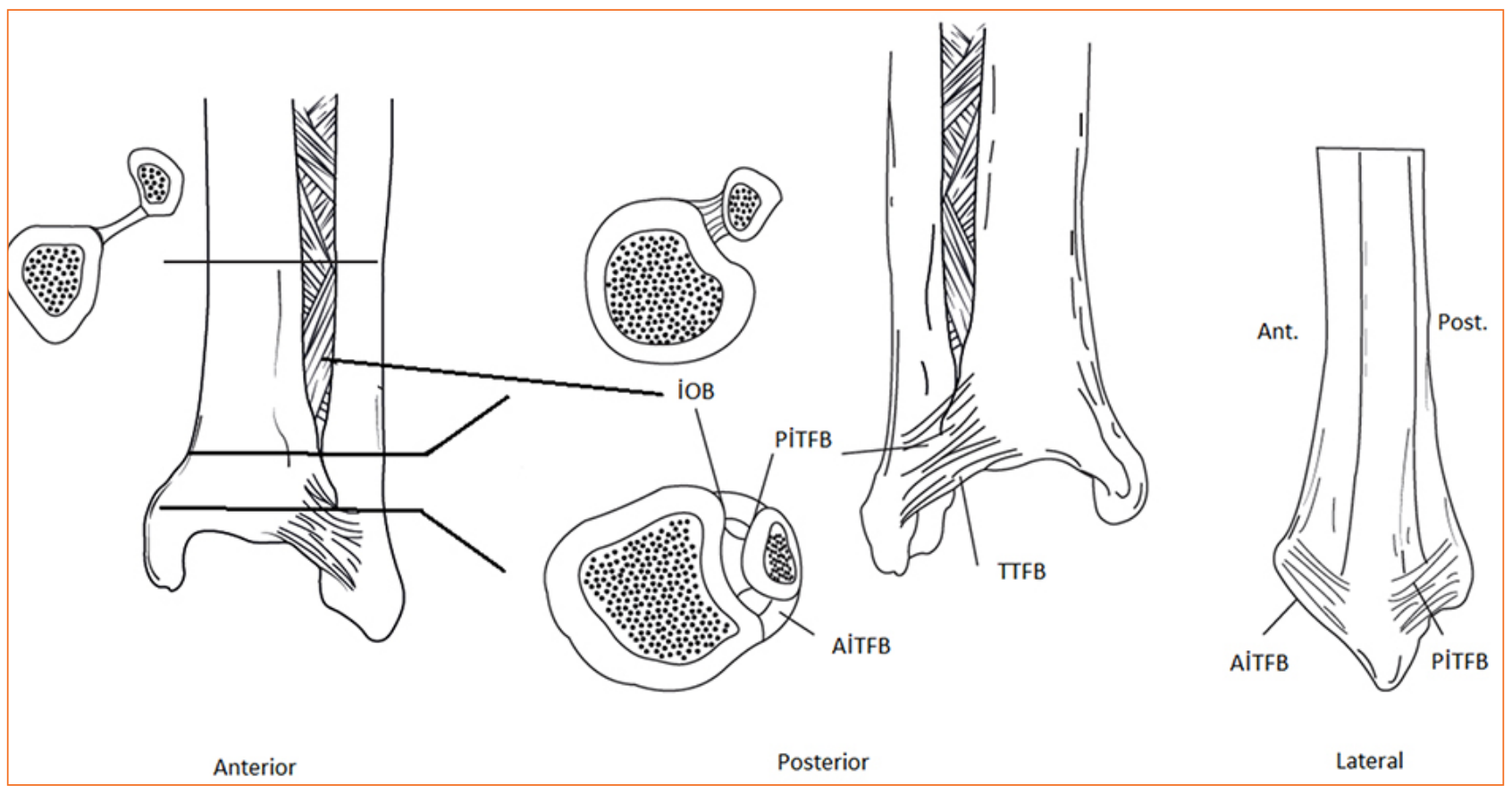

Şekil 5. Sindezmotik bağ kompleksi ve bileşenleri.

kısıtlayan, subtalar eklemin en önemli sabitleyici bağlarındandır.

2- Mediyal kollateral bağ kompleksi: Yüzeyel ve derin deltoid bağ olmak üzere iki katmandan oluşur.

a- Yüzeyel deltoid bağ grubu: Mediyal malleol anterior kollikulusundan başlar ve üç bant halinde talusun mediyal tüberkülüne, naviküler kemiğe ve plantar kalkaneonaviküler bağ ile kalkaneusun sustentakulum tali arasına doğru uzanır. Yüzeyel deltoid bağın lifleri, fasya ve tendon kılıfları tarafından desteklenir (Şekil 4).

b- Derin deltoid bağ grubu: Mediyal malleol anterior kollikulus arka kenarı, interkolliküler çentik ve posterior kollikulustan başlar ve derin anterior ve derin posterior olmak üzere, iki grup halinde talusunun mediyal tarafında eklem yüzü içermeyen kısmına yapışır. Mediyal tarafta talusun en önemli sabitleyicisidir.

3- Sindezmotik bağ kompleksi: Ayak bileğinde, tibia ve fibula arasında yer alır. Anterior, posterior, transvers tibiofibular ve interosseöz bağ olmak üzere dört gruptan oluşur (Şekil 5). ${ }^{[1,2,4,5]}$

a- Anterior inferior tibiofibular bağ (AiTFB): Tibia distal anterior tüberkül ve anterolateral yüzeyinden fibula anterioruna oblik olarak uzanır ve Wagstaffe tüberkülüne yapışır. b- Posterior inferior tibiofibular bağ (PiTFB): Tibia distal posterior tüberkülden fibula posterioruna yapışır. Kısa ve kalın bir bağ olması nedeniyle yaralanma sonrası tibia posterior tüberkül kopma kırıkları oluşabilir. Anterior tibiofibular bağ daha zayıf olduğu için, çoğunlukla anteriorda bağ yaralanması gelişir.

c- İnterosseöz bağ (IOB): Proksimal tibiofibular eklem hizasından başlayıp distale kadar uzanan interosseöz membranın devamı olup; tibiofibular eklemin sabitleyicisidir. ${ }^{[1,2,5]}$

d- Transvers tibiofibular bağ (TTFB): Tibia ve fibulanın arasında distal ve posteriorda derinde transvers olarak uzanır. Sıklıkla posterior tibiofibular bağ kompleksinin bir parçası olarak değerlendirilir.

Ayak bileğine komşu yapılar, anterior, posterior, mediyal ve lateral grup olarak ele alınabilir:

- Anterior grup yapılar: Bunlar, eklem kapsülüne yakın komşulukta olup superior ve inferior eksternal retinakulumun altında seyreder. Bu yapılara içten dışa olmak üzere; tibailis anterior tendonu, ekstansor hallusis longus tendonu, tibialis anterior arter ve veni, derin peroneal sinir, ekstansor digitorum longus tendonları ve peroneus tertius tendonudur. Anterior grup kaslar, derin peroneal sinir 


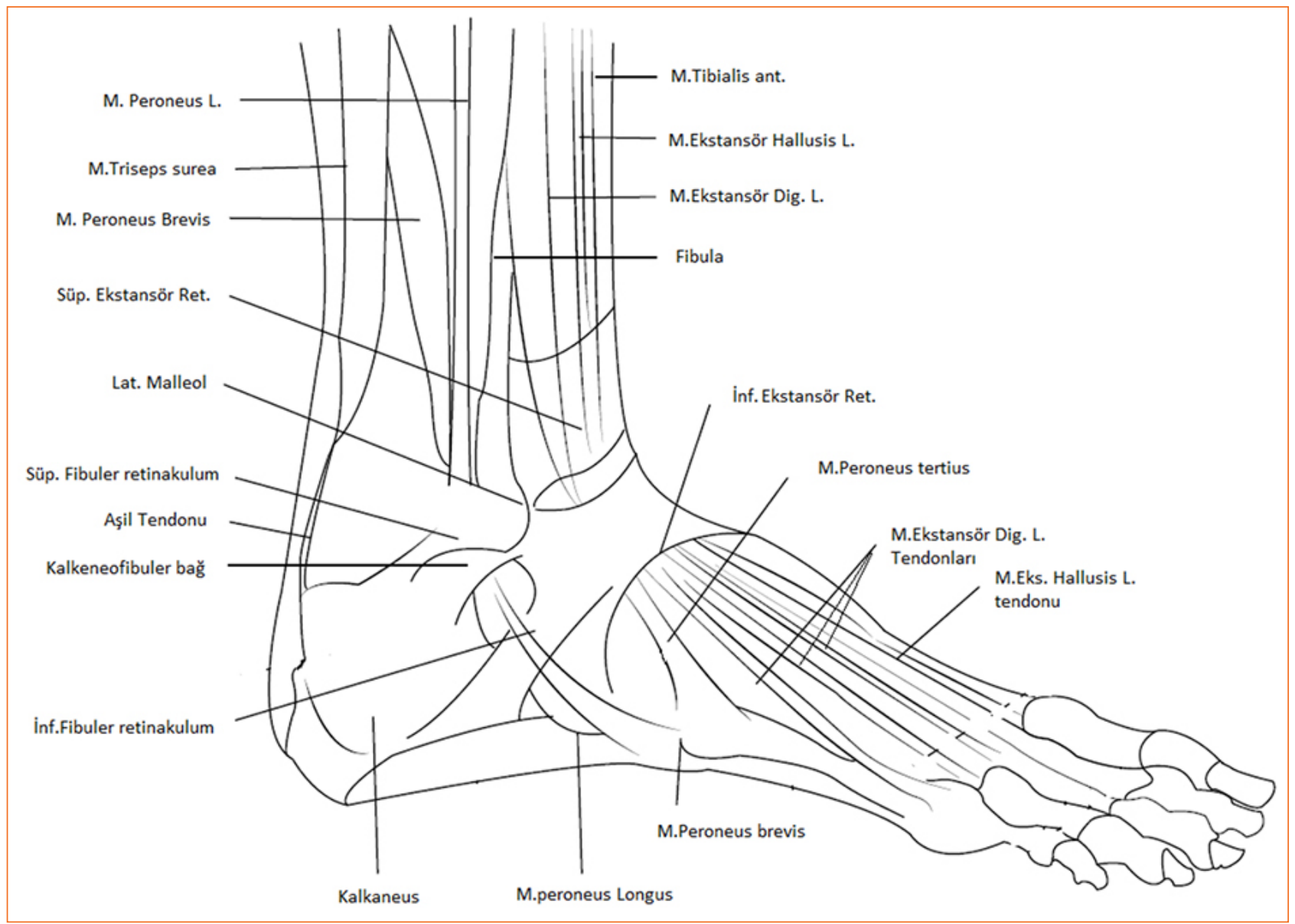

Şekil 6. Ayak bilek çevresi yapılar (antero-lateral görünüm).

tarafından innerve edilir. Duyu sinirleri yüzeyel peroneal sinir ve iç tarafta safen sinirdir (Şekil 6). ${ }^{[1,5]}$

- Lateral grup yapılar: Peroneus longus ve brevis tendonlarından oluşur. Peroneus brevis tendonu daha anteriorda seyreder. Lateral grup kaslar yüzeyel peroneal sinir tarafindan innerve edilir. Lateral bölge duyusu aşil tendonunun lateral kenarında seyreden sural sinir tarafından alınır. Peroneal kaslar, lateral malleolle kalkaneus arasında uzanan ve daha sağlam olan superior ve talusla kalkaneus arasında uzanan inferior fibular retinakulumun altından geçer. Küçük safen ven, ayak dorsalinden laterale ve lateral malleol posteriorundan orta hatta proksimale seyreder (Şekil 6). ${ }^{[1,5]}$

- Posterior grup yapılar: En belirgin olanı, ayak bileğinin en önemli plantar fleksörü olan Aşil tendonudur. Aşil tendonun lateral kenarı boyunca, ayak bilek lateralinin duyusunu alan sural sinir uzanır. Plantaris tendonu, Aşil tendonunun mediyalindedir ve posterior grubun yüzeyel tabakasında yer alır. Derin tabakada, tibial sinir, tibialis posterior arter ve veni, tibialis posterior, fleksor digitorum longus ve fleksor hallusis longus kaslarının tendonları bulunmaktadır. Posterior grup kaslar tibial sinir tarafindan innerve edilir (Şekil 7). ${ }^{[1-5]}$

- Mediyal grup yapılar: Posterior derin grup yapılar daha distalde ayak bileğinin mediyaline döner. Hep birlikte mediyal malleol distal posterioruyla kalkaneus mediyal tüberkülü arasında uzanan fleksor retinakulumun altından geçer. Fleksor retinakulum, her bir yapı için ayrı olmak üzere dört osteofibröz kanaldan oluşmaktadır. Önden arkaya; tibialis posterior tendonu, fleksor digitorum longus tendonu, tibailis posterior arter ve veni ile birlikle tibial sinir ve fleksor hallusis longus tendonu bulunmaktadır. Büyük safen ven, ayak dorsalindeki arktan başlayarak, mediyal malleol anteriorundan safen sinire ait dallarla birlikte kruris mediyalinde proksimale doğru seyreder (Şekil 7). ${ }^{[1,2,5]}$ 


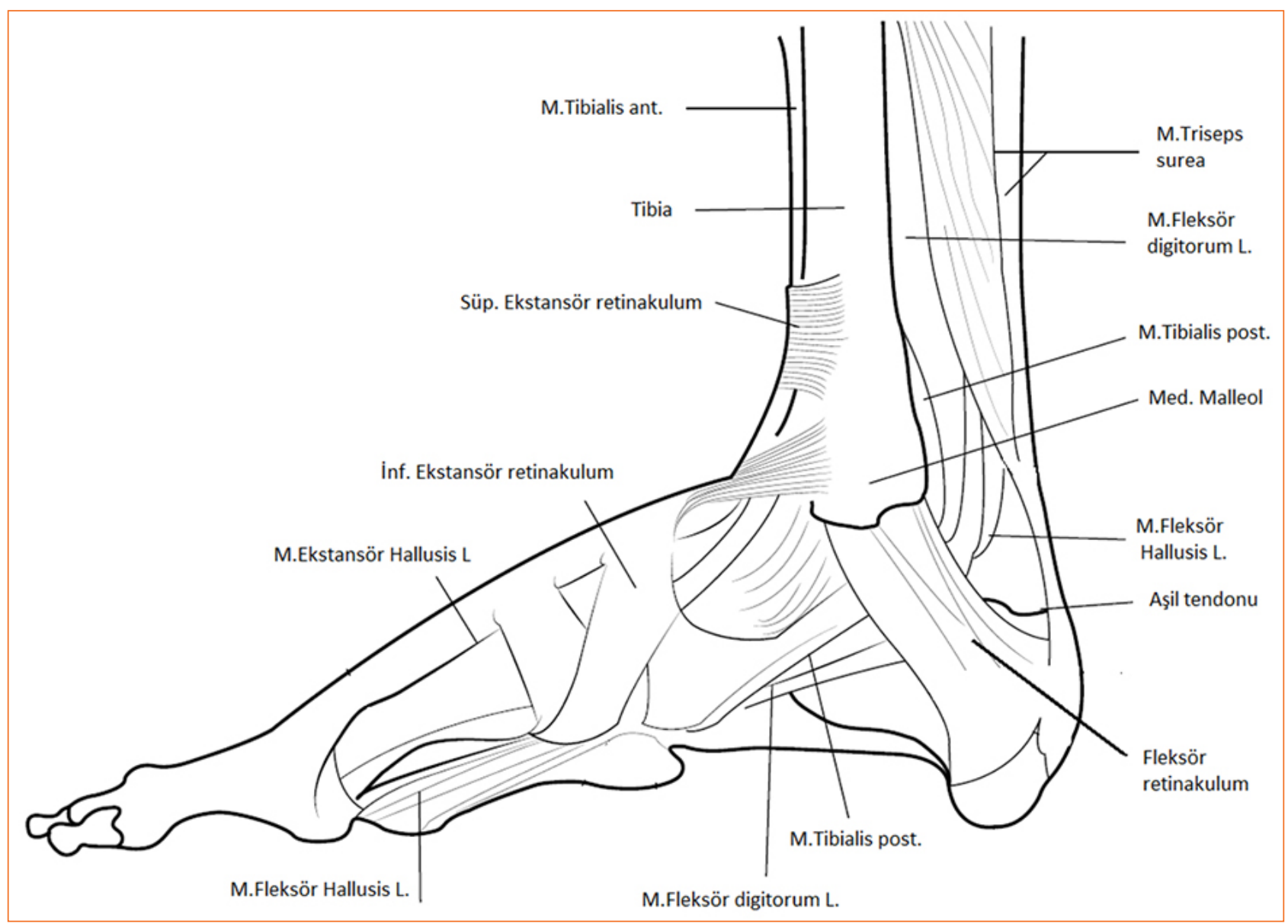

Şekil 7. Ayak bilek çevresi yapılar (mediyal görünüm).

\section{BIYOMEKANIK}

Ayak bilek hareketleri çoğunlukla tibiotalar ve subtalar eklem hareketlerini beraber ifade etmektedir. Ayak bileğinin temel hareketleri fleksiyon ve ekstansiyondur. Primer hareketler arasında rotasyon yoktur. Ayak bilek mekanik ekseni iç ve dış malleollerin uçları arasından geçmektedir (Şekil 8). Ayak bilek ekseni oblik konumda olması nedeniyle fleksiyon ve ekstansiyon sırasında ayakta sekonder olarak rotasyon hareketi gerçekleşir. Ayak bileği ekleminde, ortalama dorsal fleksiyon $20^{\circ}$, plantar fleksiyon $36^{\circ}$ dir. Ayaktaki rotasyon genişliği fleksiyon derecesine bağlı olarak $19-20^{\circ}$ 'dir. Normal yürüme için en az $10^{\circ}$ dorsifleksiyona, $20^{\circ}$ plantarfleksiyona ihtiyaç vardır. ${ }^{[1,6]}$

Tibia plafond eklem yüzeyi tibia uzun aksına göre yaklaşık $3^{\circ}(2-10)$ valgus pozisyonda açılanma yapmaktadır. Malleollerin uç noktalarından geçen ayak bilek ekseni ile tibia plafond eklem yüzeyi arasındaki açı (talokrural açı) yaklaşık olarak $8-15^{\circ}$ 'dir ve eklem dizilimi açısından önemlidir (Şekil 8). ${ }^{[2,7,8]}$
Inman, ayak bileğinde anatomi ve işlevselliği beraber düşünerek, apeksi lateralde tabanı mediyalde olan koni modelini tanımlamıştır. Tanımlanan koninin ekseni, mekanik eksendir. Bu eksen, içten dışa, önden arkaya ve yukarıdan aşağıya doğrudur. Tibianın uzun ekseniyle koronal planda $82^{\circ}$ 'lik (74-94) bir açı yapar. Ayak bilek hareketleri bu eksen etrafindaki rotasyon hareketleri olarak adlandırılabilir (Şekil 8). ${ }^{[1,6,8]}$ Hareket eksenindeki obliklik nedeniyle, ayak bileğinin pozisyonuna göre, fleksiyonda iç rotasyon, ekstansiyonda ise dış rotasyon oluşmaktadır. Ayak bileğindeki iç ve dıştaki bağ kompleksleri, rotasyon eksenine çok yakın noktalara yapışır. Bunlar, ayak bilek hareketleri sırasında çok gerilerek rotasyonel stabiliteye katkıda bulunur.

Tibiotalar eklemde talus eklem yüzeyi $2 \mathrm{~cm}$ yarıçapında bir silindirin yüzeyine eşdeğerdir. Talus $140^{\circ}$ lik bir eklem yüzeyi içermesine karşılık tibia plafond eklem yüzeyi $70^{\circ}$ lik örtünme sağlamaktadır. Bu yüzey, farkı plantar ve dorsal fleksiyondaki hareket genişliğini sağlar. ${ }^{[2,7,8]}$ 


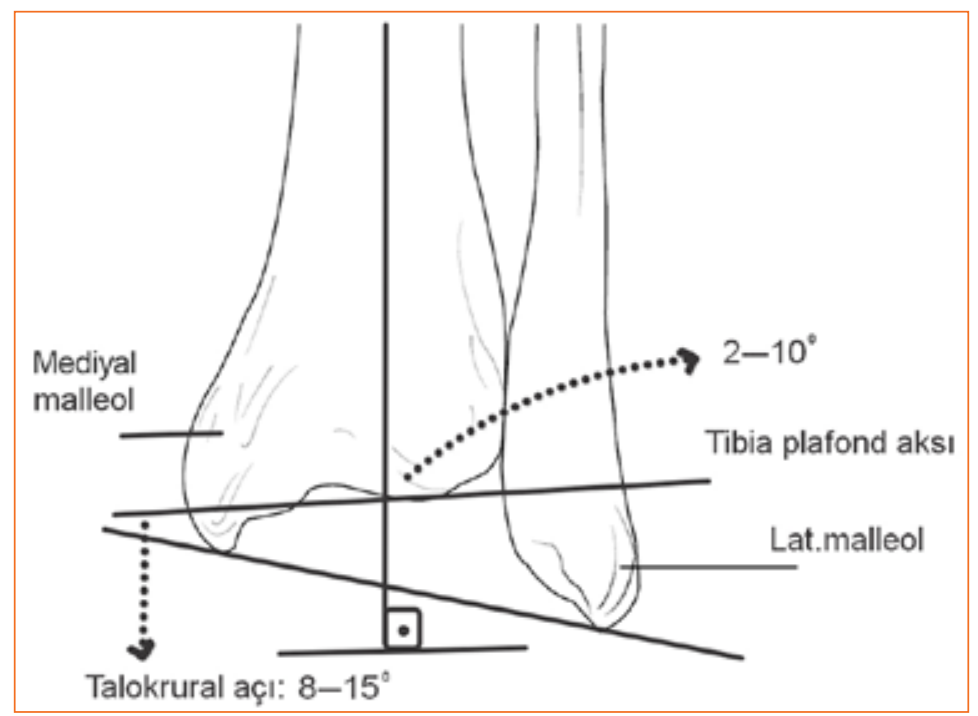

Şekil 8. Ayak bileğinde talokrural açı, mekanik ve tibia plafond aksı.
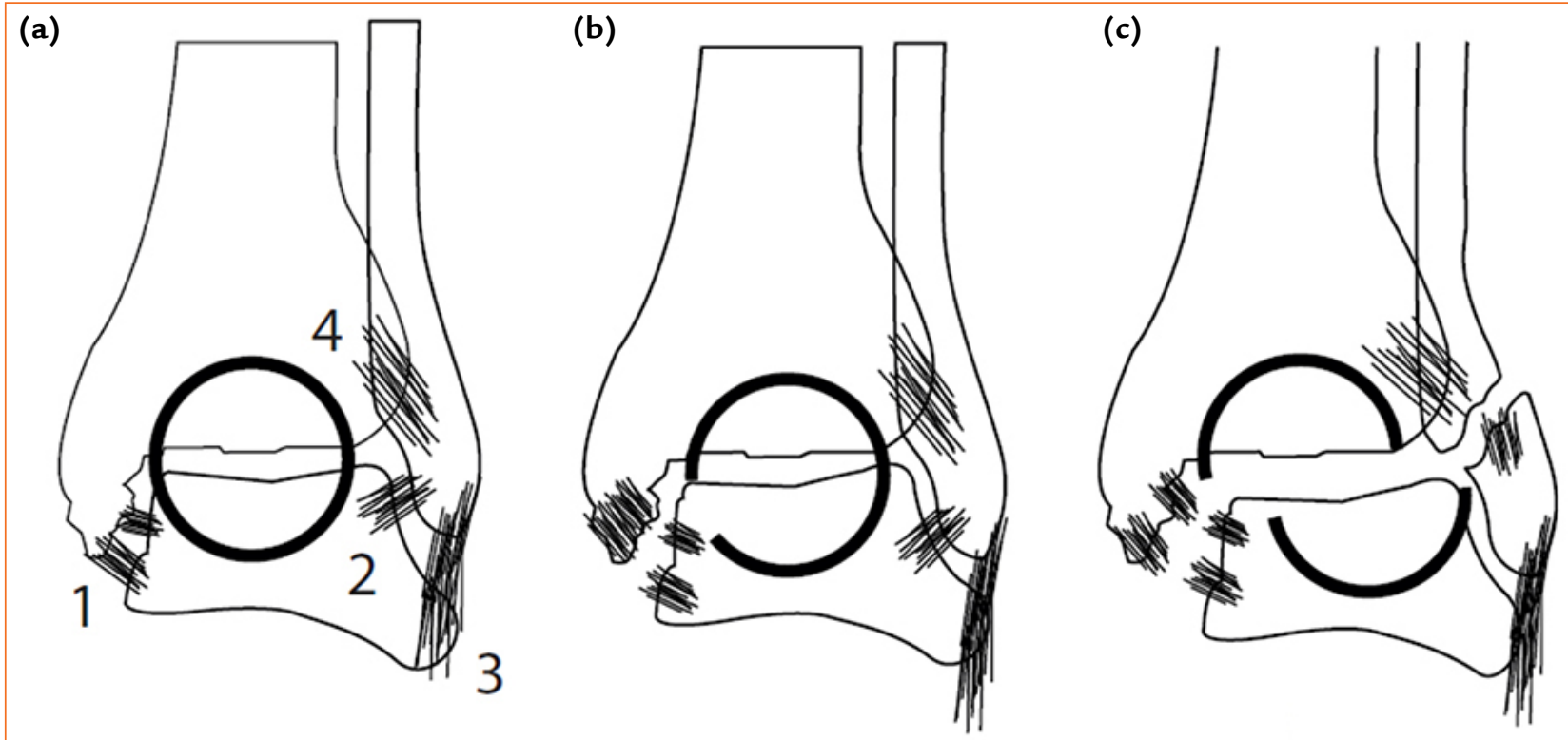

Şekil 9. Ayak bileği stabilitesinde kemik ve bağlardan oluşan izafi halka şematik görünüm. Halka stabil (a); tek noktadan bozulmasına rağmen stabil (b); birden çok noktadan noktadan bozulmuş, instabil (c).

Talusun, tibial eklem yüzeyinin ön kenarı arka kenarına göre, lateral malleol eklem yüzeyi de mediyal malleol eklem yüzeyine göre daha geniştir. Plantar fleksiyonla, fibula distale doğru hareket eder, anteromediyale kayarak içe döner. Dorsifleksiyonla, fibula proksimale doğru hareket eder, posteromediyale kayarak dışa döner. Talusun keskin ve arka kısmına göre geniş olan anterior kenarı dorsifleksiyonda ayak bileğini kısıtlarken ayak bileğini dış rotasyona zorlar. Talusun bu yapısı, bağların yardımıyla plantar fleksiyonda stabil olmakla beraber, daha hareketli yapı oluşmasını sağlar. Talus, mediyal ve lateral malleol arasındaki bu ilişki nedeniyle, ayak bileğinde hareketlerinde ve yük verildiğinde genişleme 1 mm'den az olmaktadır. ${ }^{[1,6,7,9]}$

Ayak bileğinde stabilite, mevcut kemik ve bağ kompleksleriyle (halka şeklinde) sağlanmaktadır. Bu izafi halka, mediyal malleol ve mediyal bağ kompleksi, lateral malleol ve lateral bağ kompleksi, ön sindezmotik bağ ve yapışma yerleri, arka sindezmotik bağ ve arka malleolden oluşmaktadır (Şekil 9). Bu halkanın tek bir 
yerden kırılması, talusun ayak bileğinde ön-arka veya lateral-mediyal yönde yer değiştirmesine neden olmamaktadır. İnstabilitenin gelişmesi için, halkanın en az iki noktadan bozulması gerekmektedir.

Vücut ağırlığının 1/6'sı fibula distali, geri kalanı ise tibia distali aracılığıyla alt kısımlara iletilmektedir. Ayak bileğinin yük taşıyan eklem yüzeyi, hem kalça hem de diz eklem yüzeylerine göre daha geniştir. Talustaki yer değiştirme, yük taşıyan kısımda azalmaya diğer bölümlerde aşırı yüklenmeye neden olur. Talustaki $1 \mathrm{~mm}$ deplasman, eklem temas yüzeyini \%42 oranında azaltmaktadır. ${ }^{[1,10,11]}$

\section{Teşekkür}

Çizimleri, kadavra disseksiyonlarından ve maketlerden özgün resim olarak gerçekleştiren Aykut Ateş'e sonsuz teşekkürler.

\section{KAYNAKLAR}

1. Marsh JL, Saltzman CL. Ankle Fractures. In: Bucholz RW, Heckman JD, Court-Brown CM, Koval KJ, Tornetts III P, Wirth MA, editors. Rockwood and Green's fractures in adults (Vol. 2), 6th ed. Philadelphia: Lippincott; 2006. p.2148-249.

2. Ferner $\mathrm{H}$, Staubesand J. Sobotta İnsan Anatomisi Atlası (Türkçe Çeviri). Türkçeleştirme editörü: Akıncı K, 18. Baskı, Cilt 2. İstanbul: Atlas Tıp Kitapçılık; 1985.
3. Greenspan A, Chapman NW. Lower Limb 3: Ankle and Foot. In: Greenspan A, Chaoman NW, editors. Orthopaedics Imaging. 4th ed. Philadelphia: Lippincott Williams \& Wilkins; 2004. p.293-347.

4. Schünke M, Schulte E, Schumacher U, Voll M, Wesker K. Promethaus Anatomi Atlası. Genel Anatomi ve Hareket Sistemi (Türkçe çeviri). Türkçeleştirme editörleri: Yıldırım M, Marur T. 1. Baskı, Cilt 1. İstanbul: Nobel Tıp Kitapları; 2007.

5. Pansky B, Gest TR. Lippincott Açıklamalı İnsan Anatomisi Atlası (Türkçe çeviri). Türkçe çeviri editörü: Karahan ST, Cilt 1. İstanbul: Güneş Tıp Kitabevleri; 2015.

6. Jahss $\mathrm{MH}$. Examination. In: Jahss $\mathrm{MH}$, editor. Disorders of the foot and ankle. Medical and Surgical Management (Vol. 1), 2nd ed. Philadephia: W.B. Saunders; 1992. p.41-51.

7. Koval KJ, Zuckerman JD. Hareket Sistemi Kırıkları ve Çıkıkları (Türkçe çeviri). Türkçeleştirme editörü: Şaylı U. 2. Baskı. İstanbul: Güneş Kitabevleri; 2004.

8. Carr JB. Malleolar Fractures and Soft Tissue Injuries of the Ankle. In: Browner BD, Jupiter BJ, Levin MA, Trafton PG, editors. Skeletal Trauma (Vol. 2), 3rd ed. Philadelphia: WB Saunders; 2003. p.2307-74.

9. Beumer A, Valstar ER, Garling EH, Niesing R, Ranstam J, Löfvenberg R, Swierstra BA. Kinematics of the distal tibiofibular syndesmosis: radiostereometry in 11 normal ankles. Acta Ortop Scand 2003;74(3):337-43.

10. Egol KA, Sheikhazadeh A, Mogatederi S, Barnett A, Koval KJ. Lower-extremity function for driving an automobile after operative treatment of ankle fracture. J Bone Joint Surg Am 2003;85-A(7):1185-9.

11. Ramsey PL, Hamilton W. Changes in tibiotalar area of contact caused by lateral lateral shift. J Bone Joint Surg Am 1976;58(3):356-7. 